\title{
OPTIMIZATION OF CULTIVATION TECHNOLOGY OF SUNFLOWER HYBRIDS IN THE CONDITIONS OF THE SOUTH OF UKRAINE
}

\section{Nesterchuk V. V.}

\section{INTRODUCTION}

In Ukraine, more than $90 \%$ of vegetable fats are produced from sunflower seeds. This crop is attractive to agricultural producers of the Steppe zone due to low production expenditures for the cultivation, the stability of demand for seeds and its high price in the market. A comparison of the global economic indexes of the world agriculture shows that the main oil crop in the vast majority of countries of the world is soybean. However, in Ukraine from a historical point of view and as a result of the specific regional peculiarities, particularly, favor of the soil-climatic conditions for cultivation of sunflower, the main oil crop was and is sunflower ${ }^{123}$.

The importance of this crop in food supply of the state, as well as an important export component, cannot be overestimated. Sunflower cultivation allows obtaining of two most important products, which have exceptional significance for the development of the food base of Ukraine - it is, firstly, a valuable vegetable oil, which is not inferior to animal fats by its nutritional value, and, secondly, cake (meal) that is a very valuable ingredient for balancing forage by the protein and amino acids, which is widely used in livestock, poultry farming, fish farming, etc. ${ }^{4}$. At present and on prospect, an actual problem is to increase the economic and energy efficiency of sunflower and to ensure the growing needs in high-quality seeds at the expense of selection of hybrid assortment, optimization of plants density and application of scientifically substantiated fertilization system, including the

\footnotetext{
1 Адаменко Т. Перспективи виробництва соняшнику в Україні в умовах зміни клімату. Агроном. 2005. №1. С. 12-14.

2 Ушкаренко В. О., Лазер П. Н., Шепель А. В. Економічна та біоенергетична ефективність вирощування соняшника різних груп стиглості в основних посівах при зрошенні. Таврійський науковий вісник. 1998. Вип. 8. С.10-15.

${ }^{3}$ Методика проведения полевых агротехнических опытов с масличными культурами / под общей редакцией В. М. Лукомца. Краснодар, 2007. С. 122-129.

4 Миронова Н. М. Напрямки зниження та шляхи вдосконалення структури виробничих витрат. Таврійський науковий вісник. 2006. Вип. 44. С. 326-333.
} 
application of foliar fertigation with complex fertilizers containing microelements 5 .

By commercial value, sunflower is not inferior to such important and widespread crops as wheat, corn, soybean, etc., and it is one of the most popular oilseed crops of Ukraine and other countries. The simplified cultivation technology and the high level of profitableness and profitability, increasing demand for seeds and sunflower oil in the domestic and world markets raises the need to increase acreage and increase the productivity of the crop ${ }^{6}$.

However, according to the researches and experience of producers at the production level, the genetic potential of sunflower is not opened by $50-70 \%$. It is proved that the efficiency of agricultural production belongs to complicated interrelated economic categories, which are based on the functioning of the systems of objective economic laws. It reflects one of the most important aspects of social production - effectiveness, which is reflecting the form and purpose of the process of agricultural production. Moreover, providing the characteristic of the final result, it is necessary to distinguish between the terms of the effect and the economic efficiency of the investigated elements of cultivation technologies of crops, including sunflower.

Economic and energy efficiency of production and processing of sunflower depends on the intricate complex of natural-economic, technological, scientific-technical and other factors. To optimize the cultivation technology, increase economic and energy efficiency, the following main peculiarities should be taken into account: high level of requirements to cultivation conditions; hypersensitivity to herbicides; possibility of epiphytotia of the agents of diseases, which can lead to significant loss of yield and deterioration of seed quality ${ }^{78}$.

\section{Dynamics of the product process indexes of sunflower plants depending on the hybrid assortment, plant density and microfertilizers}

The field experiments with sunflower hybrids were carried out during 2014-2016 at the research farm «Kopani» of the Institute of Irrigated Agriculture of NAAS of Ukraine according to the generally accepted

\footnotetext{
${ }^{5}$ Удова Л.О. Підвищення стійкості виробництва соняшнику. Економіка АПК. 2003. №9. C. 32-37.

6 Лукашев А. И., Тишков Н. М., Лукашев А. А. Новая система применения минеральных удобрений под подсолнечник на выщелоченных черноземах. Науч.-техн. бюлл. ВНИИ масличных культур. Краснодар, 1986. Вып. 1. С. 14-21.

7 Реймов Н. Б., Турдышев Б. Х. Технология возделывания подсолнечника. Аграрна наука. 2003. № 12. С. 10-11.

${ }^{8}$ Пабат I. А., Шевченко М. С. Індустріальна технологія вирощування соняшнику. Вісник аграрної науки. 2004. № 12. С. 16-19.
} 
methods of the experimental work ${ }^{9}$. The experiment was conducted in four replications, the sowing area of the third order plots $-101.6 \mathrm{~m}^{2}$, the accounting area $-50.96 \mathrm{~m}^{2}$. The experimental plot was rectangular, the design of the study was randomized. Complex fertilizers were applied manually using hand-syringe at the stage of 5-6 crop leaves of sunflower.

The economic efficiency of production of the studied crop was defined according to the analysis of the following indexes: yield, production expenditures per the unit of area, the cost of $1 \mathrm{c}$ of seeds, profit per 1 hectare of crops and the level of profitability ${ }^{10}$. To perform calculations on the economic efficiency of the studied elements of the cultivation technology of sunflower hybrids Megasan, Yason and Darii we have taken the stock prices for seeds and market prices for agricultural resources, which were formed during the October of 2016. In the calculation of the energy efficiency the methodology was used.

The calculations have proved that the duration of the inter-stage periods of the studied hybrids of sunflower depended significantly both on their genetic characteristics and current metrological conditions, particularly, on the amount of atmospheric precipitation during the vegetation period of the crop (Table 1).

The longest inter-stage period from the sprouting to the formation of head within 69-78 days was observed in 2015. The shortest one - of 812 days, in all the years of the study was an initial period of the development «sowing-sprouting», and also in the conditions of high temperature regime the shortest inter-stage period was «formation of head - flowering» in 2014, which lasted for 8-13 days.

The vegetation period was the maximum - at the level of 144 days, in 2015 in the hybrid of Megasan, and the shortest - 114 days in the hybrid of Darii in 2016, which is less by $26.3 \%$.

On average for the years of the study, the longest duration of the vegetation period of 134 days was in the hybrid Megasan, and in other studied hybrids this index decreased to $124-130$ days or by $3.3-8.1 \%$.

9 Ушкаренко В. О., Нікішенко В. Л, Голобородько С. П., Коковіхін С. В. Дисперсійний і кореляційний аналіз результатів польових дослідів : монографія. Херсон : Айлант, 2009. 372 с.

${ }^{10}$ Методика определения экономической эффективности использования в сельском хозяйстве результатов научно-исследовательских и опытно-конструкторских работ, новой техники, изобретений и рационализаторских предложений. К.: Урожай, 1986. $117 \mathrm{c}$. 
Table 1

Duration of the inter-stage periods of sunflower hybrids

\begin{tabular}{|c|c|c|c|c|c|c|}
\hline \multirow{2}{*}{$\begin{array}{c}\text { Year/ } \\
\text { Hybrids }\end{array}$} & $\begin{array}{c}\text { Sowing- } \\
\text { sprouting }\end{array}$ & $\begin{array}{c}\text { Sprouting- } \\
\text { formation } \\
\text { of head }\end{array}$ & $\begin{array}{c}\text { Formation } \\
\text { of head- } \\
\text { flowering }\end{array}$ & $\begin{array}{c}\text { Flowering- } \\
\text { ripening }\end{array}$ & $\begin{array}{c}\text { Sprouting- } \\
\text { ripening }\end{array}$ & $\begin{array}{c}\text { Vegetation } \\
\text { period }\end{array}$ \\
\hline \multicolumn{7}{|c|}{2014} \\
\hline Megasan & 9 & 68 & 12 & 47 & 127 & 136 \\
\hline Yason & 11 & 61 & 13 & 46 & 120 & 131 \\
\hline Darii & 11 & 59 & 8 & 47 & 114 & 125 \\
\hline \multicolumn{7}{|c|}{2015} \\
\hline Megasan & 8 & 78 & 22 & 36 & 136 & 144 \\
\hline Yason & 10 & 72 & 24 & 33 & 129 & 139 \\
\hline Darii & 11 & 69 & 21 & 32 & 122 & 133 \\
\hline \multicolumn{7}{|c|}{2016} \\
\hline Megasan & 11 & 52 & 14 & 45 & 111 & 122 \\
\hline Yason & 12 & 49 & 18 & 40 & 107 & 119 \\
\hline Darii & 9 & 51 & 15 & 39 & 105 & 114 \\
\hline \multicolumn{7}{|c|}{ The average for $2014-2016$} \\
\hline Megasan & 9 & 66 & 16 & 43 & 125 & 134 \\
\hline Yason & 11 & 61 & 18 & 40 & 119 & 130 \\
\hline Darii & 10 & 60 & 15 & 39 & 114 & 124 \\
\hline
\end{tabular}

In the variants with different degrees of thickening of the plants and application of microfertilizers, the duration of the inter-stage $\backslash$ periods and the length of the vegetation period was virtually identical, there were found weak trends (for 1-3 days) to acceleration of the ripening of the hybrids at the plants density of 50-60 thousand/ha and, on the contrary, to delaying of the inter-stage periods at the treatment of the crops with microfertilizers, especially in the variant of the treatment with the preparation Master.

On average for the years of the study, the highest level of the plant height - 194.3-199.6 cm - was observed in the variants with hybrid Megasan at the plants density of 50-60 thousand/ha and at application of Vuksal and Master preparations. The smallest $(163.3 \mathrm{~cm})$ figure was in the variant with hybrid Darii at the least plants density of 30 thousand/ha and without application of the complex microfertilizers (Table 2).

Biometric measurements have proved that on the average by the studied factors, the plant height significantly varied depending on the hybrid and to a lesser extent - on the options of plants density and application of microfertilizers. On the average, hybrid Megasan reached the height of $189.8 \mathrm{~cm}$, and hybrids Darii and Yison had the decreased height to 172.4$178.7 \mathrm{~cm}$ or by $6.2-10.1 \%$. 
Table 2

The height of the sunflower plants depending on the hybrid assortment, plants density and microfertilizers at the flowering stage, $\mathrm{cm}$

(the average for 2014-2016)

\begin{tabular}{|c|c|c|c|c|c|c|c|c|}
\hline \multirow{2}{*}{$\begin{array}{c}\text { Hybrid } \\
\text { (Factor } \\
\text { A) }\end{array}$} & \multirow{2}{*}{$\begin{array}{c}\text { Plants } \\
\text { density, } \\
\text { thousan } \\
\text { d/ha } \\
\text { (Factor } \\
\text { B) }\end{array}$} & \multicolumn{5}{|c|}{ Fertilization (Factor C) } & \multirow{2}{*}{$\begin{array}{c}\text { Avera } \\
\text { ge by } \\
\text { the } \\
\text { Factor } \\
\text { A }\end{array}$} & \multirow{2}{*}{$\begin{array}{c}\text { Avera } \\
\text { ge by } \\
\text { the } \\
\text { Facto } \\
\text { r B }\end{array}$} \\
\hline & & $\begin{array}{l}\text { Control } \\
\text { (no } \\
\text { fertilizer) }\end{array}$ & $\begin{array}{c}\text { ROST } \\
- \\
\text { conce } \\
\text { ntrate }\end{array}$ & Vuksal & Master & Average & & \\
\hline \multirow{4}{*}{$\begin{array}{c}\text { Megasa } \\
\mathrm{n}\end{array}$} & 30 & 179.5 & 185.1 & 186.5 & 188.2 & 184.8 & \multirow{4}{*}{189.8} & 176.5 \\
\hline & 40 & 181.8 & 189.9 & 191.4 & 192.7 & 188.9 & & 179.4 \\
\hline & 50 & 182.4 & 192.6 & 194.3 & 196.3 & 191.4 & & 181.6 \\
\hline & 60 & 183.5 & 195.4 & 197.5 & 199.6 & 194.0 & & 183.7 \\
\hline \multirow{4}{*}{ Yason } & 30 & 168.4 & 176.1 & 176.2 & 178.1 & 174.7 & \multirow{4}{*}{178.7} & \\
\hline & 40 & 173.5 & 178.1 & 178.9 & 182.3 & 178.2 & & \\
\hline & 50 & 174.8 & 179.9 & 181.1 & 183.7 & 179.9 & & \\
\hline & 60 & 174.9 & 182.0 & 184.3 & 187.4 & 182.2 & & \\
\hline \multirow{4}{*}{ Darii } & 30 & 163.3 & 171.3 & 171.9 & 173.3 & 169.9 & \multirow{4}{*}{172.4} & \\
\hline & 40 & 166.2 & 170.0 & 172.7 & 175.1 & 171.0 & & \\
\hline & 50 & 167.7 & 174.3 & 176.0 & 176.6 & 173.6 & & \\
\hline & 60 & 168.1 & 175.3 & 177.2 & 179.5 & 175.0 & & \\
\hline \multicolumn{2}{|c|}{$\begin{array}{c}\text { Average by the } \\
\text { Factor C }\end{array}$} & 173.7 & 180.8 & 182.3 & 184.4 & 180.3 & & \\
\hline \multicolumn{9}{|c|}{ The least significant differences $(\mathrm{cm})$ : } \\
\hline \multicolumn{9}{|c|}{ An estimation of the partial differences for the factors: $\mathrm{A}-1.22 ; \mathrm{B}-1.47 ; \mathrm{C}-0.95$} \\
\hline \multicolumn{9}{|c|}{ An estimation of the essential (main) effects: $\mathrm{A}-2.13 ; \mathrm{B}-1.70 ; \mathrm{C}-1.19$} \\
\hline
\end{tabular}

It was established that the increase of the plant density from 30 to 60 thousand/ha caused the proportional increase in the plant height on all the studied hybrids, which can be explained by the aggravation of the competition between the plants for the territory, solar energy, moisture and nutritive substances of the soil. The minimum value $-176.5 \mathrm{~cm}-$ was reached in the variant with the plant density of 30 thousand/ha. With the increase of sowing density up to 40-60 thousand/ha, the plant height in the flowering stage has slightly increased up to $179.4-183.7 \mathrm{~cm}$ or by $1.6-4.1 \%$.

Formation of the indexes of crude biomass was caused by the genetic potential of the studied hybrids, plants density and application of the microfertilizers ROST-concentrate, Vuksal and Master. The maximum value of 31.3-32.2 the studied parameter reached at the cultivation of hybrid Megasan with the plant density of 60 thousand per 1 hectare and at use of microfertilizers Vuksal and Master. The best biomass indexes of hybrids Megasan and Yason were obtained at the plant density of 50-60 thousand/ha, and of hybrid Darii - at the density of 40-60 thousand/ha. 
The analysis of the obtained results on the formation of dry matter depending on the factors and variants of the experiment indicates similar tendencies, which were found during the characteristics of the formation of crude biomass (Table 3 ).

More than 5 tons per 1 hectare of dry matter were obtained in the variant with hybrid Megasan at the plant density of 50 and 60 thousands per hectare and application of the microfertilizers ROST-concentrate, Vuksal and Master. It should be noted that hybrid Megasan was also noticeably different from the other hybrids in the formation of dry matter on the average by the Factor A. On the first of the hybrids, the index increased to $4.4 \mathrm{t} / \mathrm{ha}$, and in the variants with Darii and Yason - the yield of dry matter per the unit of sowing area decreased to $3.49-3.81 \mathrm{t} / \mathrm{ha}$ or by $15.4-26.0 \%$.

The studied range of the plant density had an unequal effect on the formation of the dry matter yield in different hybrids. In particular, at the cultivation of hybrids Megasan and Yason the best results were provided by the density of plants of 50-60 thousand/ha, and in the variant with hybrid Darii the advantageous was the plant density of 50 thousand/ha.

Table 3

The index of the dry matter yield of sunflower at the stage of seed ripening depending on the hybrid assortment, plant density and microfertilizers, $t /$ ha (the average for 2014-2016)

\begin{tabular}{|c|c|c|c|c|c|c|c|c|}
\hline \multirow{2}{*}{$\begin{array}{l}\text { Hybrid } \\
\text { (Factor } \\
\text { A) }\end{array}$} & \multirow{2}{*}{$\begin{array}{c}\text { Plant } \\
\text { density, } \\
\text { thousand/ha } \\
\text { (Factor B) }\end{array}$} & \multicolumn{5}{|c|}{ Fertilization (Factor C) } & \multirow{2}{*}{$\begin{array}{c}\text { Average } \\
\text { by the } \\
\text { Factor } \\
\text { A }\end{array}$} & \multirow{2}{*}{$\begin{array}{c}\begin{array}{c}\text { Average } \\
\text { by the } \\
\text { Factor } \\
\text { B }\end{array}\end{array}$} \\
\hline & & $\begin{array}{c}\text { Control } \\
\text { (no } \\
\text { fertilizers) }\end{array}$ & $\begin{array}{c}\text { ROST- } \\
\text { concentrate }\end{array}$ & Vuksal & Master & Average & & \\
\hline \multirow{4}{*}{ Megasan } & 30 & 3.34 & 3.65 & 3.98 & 4.26 & 3.81 & \multirow{4}{*}{4.40} & 3.53 \\
\hline & 40 & 3.54 & 4.21 & 4.55 & 4.60 & 4.23 & & 3.63 \\
\hline & 50 & 3.90 & 4.55 & 4.81 & 5.11 & 4.59 & & 4.12 \\
\hline & 60 & 4.08 & 5.01 & 5.29 & 5.45 & 4.96 & & 4.31 \\
\hline \multirow{4}{*}{ Yason } & 30 & 3.10 & 3.47 & 3.67 & 3.50 & 3.44 & \multirow{4}{*}{3.81} & \\
\hline & 40 & 3.12 & 3.53 & 3.54 & 3.87 & 3.51 & & \\
\hline & 50 & 3.62 & 3.87 & 4.01 & 4.56 & 4.01 & & \\
\hline & 60 & 3.78 & 4.19 & 4.39 & 4.72 & 4.27 & & \\
\hline \multirow{4}{*}{ Darii } & 30 & 2.87 & 3.24 & 3.34 & 3,51 & 3.22 & \multirow{4}{*}{3.49} & \\
\hline & 40 & 2.89 & 3,37 & 3.38 & 3,60 & 3.26 & & \\
\hline & 50 & 3.36 & 3.62 & 3.96 & 4.16 & 3.77 & & \\
\hline & 60 & 3.32 & 3.56 & 3.88 & 3.98 & 3.70 & & \\
\hline \multicolumn{2}{|c|}{$\begin{array}{c}\text { Average by the Factor } \\
\text { C }\end{array}$} & 3.41 & 3.84 & 4.07 & 4.28 & 3.90 & & \\
\hline \multicolumn{9}{|c|}{ The least significant difference (t/ha): } \\
\hline \multicolumn{9}{|c|}{ An estimation of the partial differences for the factors: $\mathrm{A}-0.49 ; \mathrm{B}-0.68 ; \mathrm{C}-0.55$} \\
\hline \multicolumn{9}{|c|}{ An estimation of the essential (main) effects: $\mathrm{A}-0.27 ; \mathrm{B}-0.21 ; \mathrm{C}-0.39$} \\
\hline
\end{tabular}

Application of microfertilizers significantly increased the yield of dry matter per the unit of sowing area from $3.41 \mathrm{t} / \mathrm{ha}$ in the control variant to 
3.84-4.28 t/ha. It was proved that on the plots where the studied preparations were applied by foliar spraying of the vegetating sunflower plants, the increase in the dry matter yield by $9.0-25.1 \%$ was recorded.

\section{Yield, economic and energy efficiency of the optimized cultivation technology of sunflower hybrids in the conditions of the South of Ukraine}

By the results of the study, it was established that due to the effect of natural factors and, first of all, the difference in the amount of atmospheric precipitation during the vegetation period of sunflower $(2014-174 \mathrm{~mm}$, $2015-240 ; 2016-162 \mathrm{~mm}$ ) there were significant fluctuations in the yields of all the studied hybrids in certain years. In unfavorable 2016, this index decreased to 14.4-16.6 c/ha that is explained by the decrease of water supply of the plants due to the deficit of precipitation and deterioration of growth processes, as well as adverse effect of air drought at the end of the vegetative period.

Plants density also led to significant fluctuations in the productivity of the plants. At the cultivation of the studied crop in 2014, there was an increase in the formation of the maximum level of seed yield (20.6$21.5 \mathrm{c} / \mathrm{ha}$ ) at the plant density of $40-50$ thousand/ha.

In the favorable conditions of 2015, the greatest yield - at the level of 22.1-22.7 c/ha was also obtained at the same plant density. Plant density of 50 thousand/ha was the best, on average by the Factor B, in 2016, when it was obtained $20.7 \mathrm{c} / \mathrm{ha}$. Consequently, in some years, which differed by the level of natural watert supply, the optimum plant density varied slightly by the variants of the experiment. On the contrary, different hybrids had different reaction on thickening, especially hybrid Darii in 2014.

In the years of the study, the efficiency of the complex fertilizers application under the plants of sunflower manifested unequally, however, on average, the positive effect of this agricultural measure, in comparison with the control plots (without treatments), fluctuated in wide range: in $2014-$ 11.5-23.1\%; in $2015-9.2-16.8$; in $2016-12.1-21.9 \%$, respectively. Thus, fertilization played a positive role in all the years of the study, even at worsening of environmental conditions, that is reduced rainfall, increased air temperatures and reduced relative humidity of air.

On average by the years of the study, there was an advantage of the cultivation of hybrid Megasan, which formed an average seed yield of $24.1 \mathrm{c} / \mathrm{ha}$ with the maximum increase to $26.2-27.4 \mathrm{c} / \mathrm{ha}$ at the plant density of 50 thousand/ha and treatment of the crops with the preparations Vuksal and Master (Table 4). 
Table 4

Seed yield of sunflower hybrids depending on the plant density and fertilization, $\mathrm{c} / \mathrm{ha}$ (the average for 2014-2016)

\begin{tabular}{|c|c|c|c|c|c|c|c|c|}
\hline \multirow[b]{2}{*}{$\begin{array}{c}\text { Hybrid } \\
\text { (Factor A) }\end{array}$} & \multirow{2}{*}{$\begin{array}{c}\text { Plant } \\
\text { density, } \\
\text { thousand/ha } \\
\text { (Factor B) }\end{array}$} & \multicolumn{5}{|c|}{ Fertilization (Factor C) } & \multirow[b]{2}{*}{$\begin{array}{l}\text { Average } \\
\text { by the } \\
\text { Factor A }\end{array}$} & \multirow[b]{2}{*}{$\begin{array}{c}\text { Average } \\
\text { by the } \\
\text { Factor B }\end{array}$} \\
\hline & & $\begin{array}{l}\text { Control (no } \\
\text { fertilizers) }\end{array}$ & $\begin{array}{c}\text { ROST- } \\
\text { concent } \\
\text { rate }\end{array}$ & Vuksal & Master & Average & & \\
\hline \multirow{4}{*}{ Megasan } & 30 & 16.8 & 18.1 & 19.6 & 21.4 & 19.0 & \multirow{4}{*}{21.9} & 17.7 \\
\hline & 40 & 19.6 & 22.6 & 23.8 & 25.7 & 22.9 & & 20.7 \\
\hline & 50 & 20.5 & 24.9 & 26.2 & 27.4 & 24.7 & & 21.6 \\
\hline & 60 & 17.8 & 20.9 & 22.5 & 23.1 & 21.1 & & 18.2 \\
\hline \multirow{4}{*}{ Yason } & 30 & 15.6 & 17.6 & 17.3 & 19.3 & 17.4 & \multirow{4}{*}{19.0} & \\
\hline & 40 & 18.2 & 19.3 & 20.0 & 22.9 & 20.1 & & \\
\hline & 50 & 19.0 & 20.9 & 21.9 & 23.7 & 21.4 & & \\
\hline & 60 & 15.7 & 17.3 & 18.3 & 17.6 & 17.2 & & \\
\hline \multirow{4}{*}{ Darii } & 30 & 14.4 & 16.3 & 16.8 & 18.1 & 16.4 & \multirow{4}{*}{17.5} & \\
\hline & 40 & 16.7 & 18.2 & 19.9 & 20.9 & 18.9 & & \\
\hline & 50 & 16.9 & 17.9 & 19.5 & 20.0 & 18.6 & & \\
\hline & 60 & 14.5 & 15.7 & 17.0 & 17.6 & 16.2 & & \\
\hline \multicolumn{2}{|c|}{ Average by the Factor $\mathrm{C}$} & 16.7 & 18.7 & 19.9 & 21.1 & 19.6 & & \\
\hline & $\begin{array}{l}\text { estimation } \\
\text { An estima }\end{array}$ & $\begin{array}{l}\text { The le } \\
\text { the partial } \\
\text { on of the ess }\end{array}$ & $\begin{array}{l}\text { ignific } \\
\text { rences } \\
\text { al (ma }\end{array}$ & $\begin{array}{l}\text { differ } \\
\text { the fac } \\
\text { effects: }\end{array}$ & $\begin{array}{l}\text { (c/ha) } \\
: A-0 \\
-0.27\end{array}$ & $\begin{array}{l}\text { B - } 0 \\
0.21 ;\end{array}$ & $\begin{array}{l}C-0.55 \\
0.39\end{array}$ & \\
\hline
\end{tabular}

Plant density caused significant fluctuations in the plants productivity. Thus, on average, the smallest level of seed yield of all the studied hybrids within 16.2-19.0 c/ha was recorded at the minimum and the maximum density of the plants -30 and 60 thousand/ha. On average by the factor, at the cultivation of hybrids Megasan and Yason, the optimal plant density was 50 thousand/ha, which provided the yields of 24.7 and $21.4 \mathrm{c} / \mathrm{ha}$. In the variant with hybrid Darii, the optimum plant density was 40 thousand/ha, which provided the yield of sunflower seeds $-18.9 \mathrm{c} / \mathrm{ha}$.

Application of the complex fertilizers ROST-concentrate, Vuksal and Master for the improvement of nutrition status had a positive effect on the productivity of all the studied in the experiment hybrids. The largest increase was provided by application of Master with the average yield of $21.1 \mathrm{c} / \mathrm{ha}$, while other fertilization options had the respective decrease by $5.7-11.4 \%$.

Processing of the experimental data by the means of ANOVA allowed defining significant fluctuations in the influence of the studied factors on the level of sunflower yield (Fig. 1). 


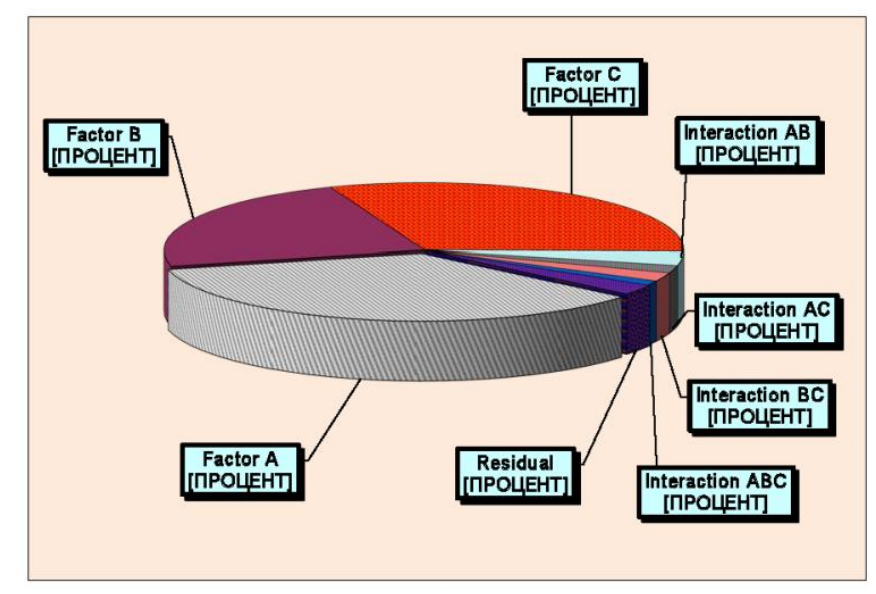

\section{Fig. 1. Share of influence of the factors on the yield of sunflower seeds depending on hybrid assortment (Factor A), plant density (Factor B) and fertilization (Factor $\mathrm{C}$ ), \%}

The greatest effect has the factor A - hybrid assortment, which ensured the formation of yield by $35.1 \%$. Fertilizers application (factor C) provided $31.2 \%$ share in the plant productivity. The share of the effect of plant density (factor B) was also high $-22.9 \%$ that is explained by the change in the reaction of sunflower hybrids on the density of crops.

The interaction of factors, as well as the residual values of the share of the impact was insignificant and fluctuated within 1.1-3.3\% with the maximum advantage of the interaction of factors A and B (hybrid assortment and plant density). During the years of the study, the share of the factors effects was subdivided as follows: Factor A (hybrids) - 35.9, 24.9, 30.8\%; Factor B (plant density) - 23.4, 20.0, 25.0\%; Factor C (fertilization) - 29.8, $40.7,26.4 \%$. Thus, the greatest fluctuations depending on the weather conditions during the vegetation period in certain years of the study from 26.4 to $40.7 \%$ have the complex fertilizers, which were applied for the improvement of nutrition conditions. The interaction of the factors and residual effect of other factors was insignificant (less than 5\%).

Laboratory analysis proved that in the years of the study the content of fat in the seeds of sunflower hybrids fluctuated to varying degrees, which was due to the influence of meteorological factors and the elements of agrotechnology. 
In the conditions of 2014, the maximum fat content in the seed of sunflower at the level of $38.5 \%$ among the studied hybrids was in the seeds of hybrid Megasan at the plant density of 30-40 thousand/ha and treatment of the crops with Vuksal and Master. This index was the minimum in the variants with hybrid Yason (29.6\%) at the plant density of 60 thousand/ha and no fertilizers applied (the control).

In the favorable 2015, the highest index (39.7\%) also was in the first hybrid, but at the plant density of 50 thousand/ha and treatment of the crops with Master.

In the conditions of drought and deficit of natural moisture in the arid 2016 year, there was the increase of the fats content in all the studied hybrids. The highest value of the investigated index within $41.5 \%$ was in hybrid Megasan at the density of the plants of 30 thousand/ha and treatment of the crops with the preparation Master.

On average by the years of the study, fat content in the seeds of sunflower depended considerably on the plant density and fertilization with micronutrient.

Among the studied hybrids, the maximum fat content was provided by hybrids Megasan - 36.9\% and Darii - 35.4\%. In the variant with hybrid Yason, the studied index decreased to 34.3 or by $4.2-7.6 \%$.

Plant density almost did not affect the content of fat, and the difference between the variants was less than the $\mathrm{LSD}_{05}$ for this factor $(0.89 \%)$ with the fluctuations of $0.8-3.8 \%$. Some tendency to the reduction of fat content in the seeds at the plan density of 60 thousand/ha could be explained by the deterioration of the nutrients and moisture supply during the growth under the increased competition in the thickened crops.

In the variant without microfertilizers application, the average fat content in the seeds of the studied crop was 33.3\%, and under the fertilization of the vegetating plants with the preparations ROST-concentrate, Vuksal and Master - increased to $34.7-37.7 \%$ or by $4.2-13.2 \%$.

The years of the study differed by natural moisture supply, which significantly affected not only the biometric parameters of the plants and yields, but also the quality indexes, particularly, the efficiency of the complex fertilizers application under the plants of sunflower. The conditional yield of oil per 1 hectare of the sowing area of sunflower in 2014 depended on the hybrid assortment, plant density and fertilization, the maximum index was $1030.9 \mathrm{~kg} / \mathrm{ha}$ in hybrid Megasan at the density of the plants of 50 thousand/ha and treatment of the crops with the preparation Master. The minimum values of the index were fixed in hybrid Darii $(437.8 \mathrm{~kg} / \mathrm{ha})$ at the maximum density -60 thousand/ha. 
Under the favorable meteorological conditions of 2015, the conditional yield of oil per one hectare of the sowing area reached the greatest values on all the hybrids, all he variants of the plants thickening and fertilization with the micronutrients. The maximum - at the level of $1118.6 \mathrm{~kg} / \mathrm{ha}$ was recorded in hybrid Megasan at the plant density of 50 thousand/ha and treatment of the crops with the preparation Master, and its lowest level $(544.1 \mathrm{~kg})$ was fixed on the untreated with the microfertilizers variants in hybrid Darii at the density of 30 thousand/ha.

Under the arid conditions of 2016 we received the lowest conditional yield values per 1 hectare of the sowing area at the level of $394.1-453.5 \mathrm{~kg}$ in the variants with hybrid Darii, the plant density of 60 thousand/ha and without application of the microfertilizers.

On average for the years of the study, a conditional yield of oil per 1 hectare of the sunflower sowing area depended on the cultivated hybrid, plant density and fertilization with the maximum index of $1077.8 \mathrm{~kg}$ in hybrid Megasan at the density of the plants of 50 thousand/ha and treatment of the crops with Master (Table 5). The lowest value of the investigated index of only $463.1 \mathrm{~kg} / \mathrm{ha}$ was fixed in hybrid Darii at the density of the plants of 60 thousand/ha and without application of the microfertilizers.

Table 5

Conditional yield of oil per 1 hectare of the sunflower sowing area depending on the hybrid assortment, plant density and fertilization,

$\mathrm{kg}$ (the average for 2014-2016 years)

\begin{tabular}{|c|c|c|c|c|c|c|c|c|}
\hline \multirow[b]{2}{*}{$\begin{array}{c}\text { Hybrid } \\
\text { (Factor } \\
\text { A) }\end{array}$} & \multirow{2}{*}{$\begin{array}{c}\text { Plant } \\
\text { density, } \\
\text { thousand/ha } \\
\text { (Factor B) }\end{array}$} & \multicolumn{5}{|c|}{ Fertilization (Factor C) } & \multirow{2}{*}{$\begin{array}{c}\begin{array}{c}\text { Average } \\
\text { by the } \\
\text { Factor } \\
\text { A }\end{array} \\
\end{array}$} & \multirow{2}{*}{$\begin{array}{c}\text { Average } \\
\text { by the } \\
\text { Factor } \\
\text { B } \\
\end{array}$} \\
\hline & & $\begin{array}{c}\text { Control } \\
\text { (no } \\
\text { fertilizers) }\end{array}$ & $\begin{array}{c}\text { ROST- } \\
\text { concentrate }\end{array}$ & Vuksal & Master & Average & & \\
\hline \multirow{4}{*}{ Megasan } & 30 & 581.7 & $\begin{array}{l}654.8 \\
\end{array}$ & 772.8 & 842.3 & 712.9 & \multirow{4}{*}{812.3} & 640.3 \\
\hline & 40 & 683.6 & 812.0 & 915.8 & 1010.6 & 855.5 & & 744.2 \\
\hline & 50 & 712.1 & 902.2 & 975.1 & 1077.8 & 916.8 & & 771.2 \\
\hline & 60 & 588.6 & 747.9 & 849.0 & 870.2 & 763.9 & & 629.6 \\
\hline \multirow{4}{*}{ Yason } & 30 & 513.1 & 600.7 & 635.3 & 711.0 & 615.0 & \multirow{4}{*}{654.8} & \\
\hline & 40 & 591.9 & 651.8 & 719.7 & 828.5 & 698.0 & & \\
\hline & 50 & 612.9 & 688.4 & 777.3 & 862.1 & 735.2 & & \\
\hline & 60 & 487.6 & 552.1 & 619.5 & 624.6 & $\begin{array}{l}571.0 \\
\end{array}$ & & \\
\hline \multirow{4}{*}{ Darii } & 30 & 487.1 & 578.3 & 621.2 & 685.8 & 593.1 & \multirow{4}{*}{622.0} & \\
\hline & 40 & 560.9 & 638.0 & 732.6 & 784.5 & 679.0 & & \\
\hline & 50 & 566.3 & 623.3 & 692.6 & 764.6 & 661.7 & & \\
\hline & 60 & 463.1 & 523.5 & 577.1 & 652.4 & 554.0 & & \\
\hline \multicolumn{2}{|c|}{$\begin{array}{c}\text { Average } \\
\text { by the Factor } \mathrm{C}\end{array}$} & 570.8 & 664.4 & 740.7 & 809.5 & 696.3 & & \\
\hline
\end{tabular}

By the first studied factor (hybrid assortment), the advantage of hybrid Megasan, which allowed obtaining in average $812.3 \mathrm{~kg} / \mathrm{ha}$ of sunflower oil, 
was proved. On hybrids Darii and Yason, these figures ranged from 622.0 to $654.8 \mathrm{~kg} / \mathrm{ha}$, which is less than the Megasan by $24.1-30,6 \%$, respectively.

Plant density to different extent affected the conditional yield of oil per the unit of sowing area. Thus, in the variant with hybrid Megasan, the greatest level of the studied index $(916.8 \mathrm{~kg} / \mathrm{ha})$ was provided by the density of the plants of 50 thousand/ha; on hybrids Yason $(698.0-735.2 \mathrm{~kg} / \mathrm{ha})$ and Darii (661.7-679.0 kg/ha) - 40-50 thousand/ha.

On average by the plant density (Factor B), the greatest yield of conditional oil $-771.2 \mathrm{~kg} / \mathrm{ha}$ was provided by the density of the plants 50 thousand/ha. At the density of the plants of 40 thousand/ha there was an insignificant decrease in the index to $744.1 \mathrm{~kg} / \mathrm{ha}$ or by $3.4 \%$. The boundary range of the crops thickening (30 and 60 thousand/ha) resulted in a significant - by $20.4-22.5 \%$ - reduction in the conditional yield of sunflower oil per the area of the research plots.

Application of the microfertilizers (ROST-concentrate, Vuksal, Master) in the recommended doses caused a significant increase in the conditional yield of oil per 1 hectare. On the untreated plots, this index was $570.8 \mathrm{~kg} / \mathrm{ha}$, and under the use of the fertilizers we recorded its rise to $664.4-809.5 \mathrm{~kg} / \mathrm{ha}$ or by $16.4-41.8 \%$.

The studied factors significantly affected on the cost of the gross product, which increased over 20 thousand/ha at the cultivation of all the studied hybrids with the density of the plants in the range of 40-60 thousand/ha and treatment with the complex fertilizers ROST-concentrate, Vuksal and Master. The lowest values of this index fluctuated from 14.0 to 17.4 thousand $\mathrm{UAH} / \mathrm{ha}$ at the minimum density of the plants (30 thousand/ha) and without application of the complex fertilizers.

Fertilization of sunflower with the complex fertilizer Master contributed to the increase of the value of the gross product per the unit of area, on average, up to 20.6 thousand/ha. In the variant with the treatment of the plants with Vuksal, this index decreased by 5.7\%, and in the areas where the ROST-concentrate was applied - by $11.4 \%$. On the whole, application of the complex fertilizers on the crops provided the increase of the gross yields by $10.7-20.9 \%$ in comparison to the control plots

By the analysis of technological maps of the cultivation of sunflower hybrids Megasan, Yason and Darii on the research plots, it was proved that the production expenditures did not change significantly depending on the change of the plant density and the use of the complex fertilizers ROSTconcentrate, Vuksal and Master.

The highest production expenditures of more than 9.6 thousand $\mathrm{UAH} / \mathrm{ha}$ were fixed in the variants with hybrid Megasan at the density of the plants of 
50-60 thousand/ha and application of the complex fertilizers Vuksal and Master, and on hybrid Yason - with the same thickening and use of Vuksal.

The calculations helped us to determine that the lowest cost of $1 \mathrm{c}$ of sunflower seeds at the level of $350.4 \mathrm{UAH}$ was in the variant with hybrid Megasan, the plant density of 50 thousand/ha and treatment of the crops with the complex fertilizer Master. The highest (at the level of $629.5 \mathrm{UAH} / \mathrm{v}$ ) figure was obtained in the variant with hybrid Darii at the density of the plant of 60 thousand/ha and without the use of the complex fertilizers.

Among the hybrids, the highest level of sunflower seeds cost had hybrids Darii and Yason, where this index increased to 532.2 and $491.9 \mathrm{UAH} / \mathrm{c}$, respectively. At the cultivation of hybrid Megasan, this index decreased by 19.5 and $12.9 \%$ - to $428.2 \mathrm{UAH} / \mathrm{c}$, which indicates the best use of monetary resources at the cultivation of this hybrid.

The maximum pure profit at the level of 17.1 thousand UAH was obtained in the variant with hybrid Megasan at the sowing with the density of 50 thousand/ha and carrying out applications with the complex fertilizer Master (Table 7).

Among the studied hybrids, Megasan also had an advantage from the point of view of the forming the largest conditional pure profit. Thus, in the variant with this hybrid, this index was, on average by the factor A, 11,975 UAH/ha, and in the variants with hybrids Darii and Yason it decreased to 7,749-9,180 UAH/ha or by 23.3-35.3\%.

Application of all the studied complex fertilizers contributed to significant (by 20.2-35.1\%) increase in the pure profit at the cultivation of hybrids Megasan, Yason and Darii. In the control variant, the minimum value of the studied index was observed - at the level of 7.2 thousand $\mathrm{UAH} / \mathrm{ha}$. The biggest pure profit was in the variant with application of the preparation Megasan, where it increased to 11.1 thousand $\mathrm{UAH} / \mathrm{ha}$, which is 1.5 times more comparing with the control variant.

The profitability level of more than $160 \%$ was observed in the variants with hybrid Megasan at the density of the plants of 40-50 thousand/ha and application of the complex fertilizers ROST-concentrate, Vuksal and Master. And the highest profitability $(178.3 \%)$ was formed at the cultivation of hybrid Megasan with the density of the plants of 50 thousand/ha and application of the complex fertilizer Master.

The gross energy income from the seed yield depended on the fluctuations in the seed yield under the influence of the studied factors - the hybrid assortment (Factor A), the plant density (Factor B), fertilization (Factor C). Among the hybrids of sunflower, the greatest energy output per the unit of area was provided at the cultivation of hybrid Megasan, where the index was $53.0 \mathrm{GJ} / \mathrm{ha}$. 
In hybrids Yason and Darii there was a decrease in the energy income with the seed yield to 45.9 and $42.3 \mathrm{GJ} / \mathrm{ha}$, or by 13.2 and $20.1 \%$.

Table 7

Pure profit received from the cultivation of sunflower depending
on the hybrid assortment, density of the plants and fertilization, UAH/ha (the average for 2014-2016)

\begin{tabular}{|c|c|c|c|c|c|c|c|c|}
\hline \multirow[b]{2}{*}{$\begin{array}{c}\text { Hybrid } \\
\text { (Factor A) }\end{array}$} & \multirow[b]{2}{*}{$\begin{array}{c}\text { Plant } \\
\text { density, } \\
\text { thousand/ha } \\
\text { (Factor B) }\end{array}$} & \multicolumn{5}{|c|}{ Fertilization (Factor C) } & \multirow[b]{2}{*}{$\begin{array}{c}\text { Average } \\
\text { by the } \\
\text { Factor A }\end{array}$} & \multirow[b]{2}{*}{$\begin{array}{c}\text { Average } \\
\text { by the } \\
\text { Factor } B\end{array}$} \\
\hline & & $\begin{array}{l}\text { Control } \\
\text { (no } \\
\text { fertilize } \\
\text { rs) }\end{array}$ & $\begin{array}{c}\text { ROST- } \\
\text { concent } \\
\text { rate }\end{array}$ & Vuksal & Master & Average & & \\
\hline \multirow{4}{*}{ Megasan } & 30 & 7,378 & 8,520 & 9,640 & 11,455 & 9,273 & \multirow{4}{*}{11,975} & 8,030 \\
\hline & 40 & 9,995 & 12,794 & 13,622 & 15,535 & 12,962 & & 10,847 \\
\hline & 50 & 10,795 & 14,959 & 15,884 & 17,114 & 14,639 & & 11,652 \\
\hline & 60 & 8,158 & 11,055 & 12,273 & 12,918 & 11,125 & & 8,335 \\
\hline \multirow{4}{*}{ Yason } & 30 & 6,233 & 8,057 & 7,423 & 9,433 & 7,738 & \multirow{4}{*}{9,180} & \\
\hline & 40 & 8,659 & 9,606 & 9,946 & 12,834 & 10,261 & & \\
\hline & 50 & 9,363 & 11,090 & 11,723 & 13,538 & 11,453 & & \\
\hline & 60 & 6,154 & 7,588 & 8,221 & 7,598 & 7,366 & & \\
\hline \multirow{4}{*}{ Darii } & 30 & 5,088 & 6,815 & 6,960 & 8,288 & 6,788 & \multirow{4}{*}{7,749} & \\
\hline & 40 & 7,228 & 8,564 & 9,880 & 10,915 & 9,122 & & \\
\hline & 50 & 7,359 & 8,208 & 9,426 & 9,973 & 8,766 & & \\
\hline & 60 & 5,010 & 6,054 & 6,979 & 7,624 & 6,417 & & \\
\hline \multicolumn{2}{|c|}{$\begin{array}{l}\text { Average by the } \\
\text { Factor C }\end{array}$} & 7,188 & 9,012 & 9,840 & 11,070 & 9,765 & & \\
\hline
\end{tabular}

According to the calculations, it was proved that the consumption of gross energy on sunflower seed production was poorly influenced by the studied factors, due to the insignificant difference between the individual technological operations and expenditure of resources on the individual variants of the cultivation technologies.

For the formation of the yield, hybrid Megasan used $18.4 \mathrm{GJ} / \mathrm{ha}$, and at the cultivation of hybrids Yason and Darii, this index decreased insignificantly (by 0.8-1.2\%) - to 18.1-18.2 GJ/ha. The maximum energy increase at the level of 34.6 GJ/ha was in the variant with hybrid Megasan, and in other hybrids this index decreased to $24.2-27.7 \mathrm{GJ} / \mathrm{ha}$, or by $19.8-30.1 \%$.

The maximum coefficient of energy efficiency (more than 3.0) in the experiment was in the variant with hybrid Megasan at the plant density of 40-60 thousand/ha and application of the complex fertilizers ROSTconcentrate, Vuksal and Master.

The analysis of the energy intensity for the production of $1 \mathrm{c}$ of sunflower seeds allowed to detremine a tendency to the reduction of this index to $0.68-0.72 \mathrm{GJ}$ at the cultivation of hybrid Megasan with the plant density of 40-50 thousand/ha and application of the complex fertilizers Vuksal and Master. 
The developed dependencies testify about the necessity for an energy substantiation of sunflower seed cultivation technologies depending on the hybrid assortment and the individual elements of cultivation technology, in particular, plant density and complex fertilizers application. Consequently, at the cultivation of hybrids with high genetic potential, it is needed to plan higher energy expenditures, which will subsequently be fully compensated by the increased yield of seeds.

\section{CONCLUSIONS}

1. By the results of the field study it was established that the highest duration of the vegetation period of 134 days was in hybrid Megasan, and in other studied hybrids, this index decreased to $124-130$ days or by $3.3-8.1 \%$. Plant height of the maximum level $-194.3-199.6 \mathrm{~cm}$ was reached on the plots with hybrid Megasan, which was cultivated with the density of 5060 thousand of the plants per 1 hectare and treatment of the crops with Vuksal and Master. The maximum output of crude biomass at the level of 31.3-32.2 t/ha was recorded at the cultivation of hybrid Megasan at the plant density of 60 thousand/ha and with application of the microfertilizers Vuksal and Master. The same hybrid provided the yield of dry matter that averaged to $4.4 \mathrm{t} / \mathrm{ha}$, and in the variants with hybrids Darii and Yason it decreased by 15.4-26.0\%.

2. The study have determined that at the cultivation of sunflower on dark-chestnut soil in the non-irrigated conditions of the South of Ukraine it is necessary to adjust the density of plants depending on the genetic potential of hybrids. To obtain the yield at the level of $23-25 \mathrm{c} / \mathrm{ha}$ it is required to sow the hybrid Megasan. The density of plants should be adjusted depending on the genetic potential of the hybrids - for hybrids Megasan and Yason the optimal density is 50 thousand/ha, and for hybrid Darii - 40 thousand/ha. Treatment of sunflower crops with the complex fertilizers provides the increase in the yield by $10.7-20.9 \%$, improves seed quality, positively reflects on the economic indicators.

3. The lowest cost of $1 \mathrm{c}$ of sunflower seed at the level of $350.4 \mathrm{UAH}$ was in the variant with hybrid Megasan, the plant density of 50 thousand/ha and treatment of the crops with the complex fertilizer Master. The level of profitability of more than $160 \%$ was fixed in the variants with hybrid Megasan at the plant density of 40-50 thousand/ha and application of the complex fertilizers ROST-concentrate, Vuksal and Master. The analysis of the energy intensity for $1 \mathrm{c}$ of sunflower seeds production allowed to determine the tendency to the reduction of this index to $0.68-0.72 \mathrm{GJ}$ at the 
cultivation of hybrid Megasan with the density of the plants of 4050 thousand/ha and application of the complex fertilizers Vuksal and Master.

\section{SUMMARY}

The article presents the results of the study on the dynamics of the indexes of production processes of sunflower hybrids depending on the differentiation of the plant density and the background of fertilization with the complex microfertilizers. It was determined that the length of the inter-stage periods of the studied sunflower hybrids significantly depended on their genetic characteristics and current metrological conditions, in particular, on the amount of atmospheric precipitation during the vegetation period of the crop. The formation of crude biomass indexes was determined by genetic potential of the studied hybrids, the density of the plants and application of microfertilizers ROST-concentrate, Vuksal and Master. The results of the field study determined that the longest duration of the vegetation period at the level of 134 days was in hybrid Megasan, and in other hybrids this index decreased to $124-130$ days or by $3.3-8.1 \%$. The maximum yield of crude biomass at the level of 31.3-32.2 t/ha was recorded at the cultivation of hybrid Megasan with the density of the plants of 60 thousand/ha and application of Vuksal and Master. The same hybrid provided the yield of dry matter at the level of 4.4 t/ha, and in the variants with hybrids Darii and Yason it decreased by 15.4$26.0 \%$. The highest yield of sunflower seeds at the level of 23-25 c/ha provided hybrid Megasan. The optimum plant density for hybrids Megasan and Yason is 50 thousand/ha, and for hybrid Darii - 40 thousand/ha. Application of the complex fertilizers on sunflower crops provides the yield increase by $10.7-20.9 \%$ and improves seed quality. Economic and energy indexes testify about high level of pure profit (10.9-17.1 thousand UAH/ha), profitability (115-178\%) and the energy coefficient (2.76-3.55) at the cultivation of the seeds of the studied crop.

\section{REFERENCES}

1. Адаменко Т. Перспективи виробництва соняшнику в Україні в умовах зміни клімату. Агроном. 2005. №1. С. 12-14.

2. Ушкаренко В. О., Лазер П. Н., Шепель А. В. Економічна та біоенергетична ефективність вирощування соняшника різних груп стиглості в основних посівах при зрошенні. Таврійський науковий вісник. 1998. Вип. 8. С. 10-15.

3. Методика проведения полевых агротехнических опытов с масличными культурами / под общей редакцией В. М. Лукомца. Краснодар, 2007. С. 122-129. 
4. Миронова Н. М. Напрямки зниження та шляхи вдосконалення структури виробничих витрат. Таврійський науковий вісник. 2006. Вип. 44. С. 326-333.

5. Удова Л.О. Підвищення стійкості виробництва соняшнику. Економіка АПК. 2003. №9. С. 32-37.

6. Лукашев А. И., Тишков Н. М., Лукашев А. А. Новая система применения минеральных удобрений под подсолнечник на выщелоченных черноземах. Науч.-техн. бюлл. ВНИИ масличных культур. Краснодар, 1986. Вып. 1. С. 14-21.

7. Реймов Н. Б., Турдышев Б. Х. Технология возделывания подсолнечника. Аграрна наука. 2003. № 12. С. 10-11.

8. Пабат I. А., Шевченко М. С. Індустріальна технологія вирощування соняшнику. Вісник аграрної науки. 2004. № 12. С. 16-19.

9. Ушкаренко В. О., Нікішенко В. Л, Голобородько С. П., Коковіхін С. В. Дисперсійний i кореляційний аналіз результатів польових дослідів : монографія. Херсон : Айлант, 2009. 372 с.

10. Методика определения экономической эффективности использования в сельском хозяйстве результатов научноисследовательских и опытно-конструкторских работ, новой техники, изобретений и рационализаторских предложений. К.: Урожай, 1986. $117 \mathrm{c}$.

\section{Information about the Author:} Nesterchuk V. V.,

Candidate (Ph.D.) of Agricultural Sciences, Director, State Enterprise Research Farm «Kopani» of the Institute of Irrigated Agriculture of the National Academy of Agrarian Sciences of Ukraine Petrivske Village, Kherson Region, 75011, Ukraine 